\title{
Accounting
}

\section{The expected impact of applying IFRS (17) insurance contracts on the quality of financial reports}

\author{
Ahmad Dahiyat ${ }^{a^{*}}$ and Walid Owais ${ }^{a}$
}

${ }^{a}$ Al-Balqa Applied University, Amman University College for Financial and Managerial Science, Jordan

\section{H R O N I C L E}

Article history:

Received: October 30, 2020

Received in revised format:

November 302020

Accepted: December 30, 2020

Available online:

December 30, 2020

Keywords:

IFRS 17

Quality of Financial reporting

Insurance Companies

Insurance Contract

Jordan

\begin{abstract}
A B S T R A C T
This study aimed to explore the expected effect of applying the International Financial Reporting Standard (IFRS) 17 Insurance Contracts on the quality of financial reports. The study followed the exploratory descriptive analytical approaches. A questionnaire was developed and distributed to a sample of 120 financial employees in all insurance companies in Jordan. It concluded that the expected impact of applying the standard on the quality of financial reports was significant, especially on the comparability of financial reports, and faithful representation. It was found that there is an expected, statistically significant and positive effect between the application of the standard, and the quality of financial reports in general, and the expected influence of applying the standard and each of comparability, faithful representation, relevance, verifiability, timely, and understandability respectively. The study recommends the application of the standard in the specified time, work to create appropriate conditions, and the need to follow objective assumptions from the company's management for the estimation of cash flows when applying the standard.
\end{abstract}

(C) 2021 by the authors; licensee Growing Science, Canada

\section{Introduction}

The International Accounting Standards Board (IASB) issued the new International Financial Reporting Standard 17 "Insurance Contracts" on 18/5/2017, to replace it with IFRS 4 "Insurance Contracts". The implementation deadline defined to be on 1/1/2021, then it has been postponed to the beginning of the year 2023, the standard can be applied before that date if the company also applies IFRS 9 "Financial Instruments" and the International Financial Reporting Standard 15 Revenue from contracts with clients at the same time (IFRS Foundation, 2020). The users of the financial reports of insurance companies faced a weakness in transparency of the information according to IFRS (4) because of disadvantages represented in the inequality in the accounting procedures provided by the standard to address some issues, such as the difference in the treatment of assets and liabilities between the historical and fair value in contracts Insurance; which required the International Accounting Standards Board to issue a financial reporting standard (insurance contracts) (17) to address these procedures, and to develop a unified general framework for dealing with insurance contracts to achieve a higher degree of fairness and transparency in the quality of financial reports. The objective of financial reporting is to provide a high-quality financial information that has a set of qualitative characteristics and help decision makers make appropriate decisions which reflects the importance of the quality of financial reports, which in turn are affected by high-quality accounting standards and their appropriate application. Based on the foregoing, this study mainly seeks to know the expected impact of applying the new standard (17) on the quality of financial reports issued by Jordanian insurance companies, in addition to know the expected effect of applying the standard on each of the qualitative characteristics of accounting information, which are: relevance, faithful representation, understandability, verifiability, timeliness, and comparability.

* Corresponding author.

E-mail address: waliiidowais@bau.edu.jo (W. Owais) 
The importance of this study stems from shedding light on a new standard that must be applied by insurance companies within a relatively short period, and thus clarifying the importance of the standard and encouraging its application, by stating the expected impact of its application on the quality of the financial reports of insurance companies, which is reflected in the decisions of the different stakeholders.

This study will contribute, through the results it will reach, to know the respondents' views of the expected effects of applying the financial reporting standard (insurance contracts) (17) on the quality of the financial reports of Jordanian insurance companies, and by addressing a relatively recent topic, and by providing a study that will enrich this topic, which suffers from the scarcity of studies covering it, especially in the Jordanian environment.

\section{The Importance of the Insurance Sector in the Jordanian Economy}

The insurance industry developed in Jordan through the establishment of the first insurance agency in 1946 which was affiliated with the Egyptian Al-Sharq Insurance Company, while the first national insurance company appeared in 1951, as the Jordanian Insurance Company. The number of companies increased in subsequent decades, eventually reaching 24 companies. Some of them (7) companies specialized in providing general insurance services, including medical insurance, and one company specialized in practicing general insurance except for medical insurance, and (15) companies provided general insurance in addition to life insurance, and one company specialized in life insurance, and there are no specialized companies with reinsurance, as the statistics of the financial indicators showed the performance of the insurance sector in Jordan as on 7/31/2020. (General Union of Insurance Companies website, Statistics 2020). At the same time, laws were issued to regulate the insurance market (Insurance Law No. 30 of 1984 and Law No. 9 of 1995), in addition to the establishment of the Jordan Insurance Federation in 1989, which replaced the Jordan Association for Insurance companies (founded in 1956) (Jordan Insurance Federation, 2020). In spite of the difficult conditions surrounding Jordan, the wheel of the local economy started to turn quickly, and the growth numbers are witness to an increase in many areas during recent years. But the emergence of the COVID-19 pandemic in 2019 and 2020 has had an impact on the insurance sector in Jordan, and this is evident through a report by the Jordan Insurance Federation on studies conducted through the first half of 2020. The following are the most important indicators of the study (Jordan Insurance Federation, 2020):

Insurance premiums: The past year has seen a decrease in written premiums of 3\%, as 2020 total premiums reached $\$ 432$ million, compared to the same period in 2019, which amounted to $\$ 446$ million. Insurance compensation: There was a decrease in the total compensation paid to the insurance market of $21.6 \%$, from $\$ 328$ million in 2019 to $\$ 257$ million in 2020 . As for the market value of insurance companies listed on the Amman Stock Exchange, according to the latest aggregate information available at the Amman Stock Exchange (2020), it reached more than $\$ 412$ million in 2018, while the volume of sector assets reached $\$ 1,040$ million in that year.

\section{Literature Review and Hypotheses}

\subsection{Literature Review}

The issue of insurance contracts passed through two phases, where the first phase ended with the issuance of Financial Reporting Standard No. (4) in the year 2004 and was considered valid as of the beginning of the year 2005, this standard has aimed to clarify how the insurance companies report on the issued and incoming insurance and reinsurance contracts, in addition it focuses on the disclosure that clarifies the amounts that must be shown in the financial statements and arising from the insurance contracts, it is concerned with disclosing the amounts, timing and uncertainty of future cash flows of insurance contracts. IFRS (4) defined an insurance contract as a contract whereby the insurance company accepts the insurance risk by the insured (IFRS Foundation, 2020). The second phase was completed in 2017 with the issuance of Financial Reporting Standard No. (17), which replaced Financial Reporting Standard (4). The new standard focused on recognition, measurement and presentation of insurance contracts and creating an accounting models for insurance contracts. IFRS (17) is considered effective and enforceable as of 1-1-2021, and the implementation has been postponed to date from 1-1-2023, but insurance companies can apply it before that date only if they apply the financial reporting standard (9) Financial Instruments and Financial Reporting Standard (15) "Revenue from Contracts with Clients". The issuance of IFRS 17 came to compensate for the weaknesses and negatives that were suffered by IFRS 4 as follows:

- According to IFRS (4) it does not require that the assets and liabilities be evaluated in insurance contracts in the way, as the assets are evaluated at their fair value while the liabilities are evaluated based on the historical value (Al-Mashhadani \& AlZubaidi, 2020). IFRS 17 will unify the valuation of assets and liabilities based on fair value. Using assumptions related to updated cash flow based on the discount rate and risk through specific specifications that must be characteristics of the discount rates used to discount cash flows under IFRS (17), thus providing a fair and transparent basis for the corresponding process in insurance contracts.

- IFRS 4 does not require that accounting for various insurance contracts be carried out in a consistent manner. As companies can carry out accounting procedures for insurance contracts differently among themselves, but accounting for insurance contracts can be done differently within the company itself, which has negatively affected the difficulty of determining which group of insurance 
contracts in the company is profitable and which one is losing. As well as the difficulty of conducting trend analysis on insurance contract information; Therefore, the issuance of IFRS 17 aimed to provide a unified basis for accounting for all types of insurance contracts and reinsurance contracts, thus providing a unified basis for the possibility of the comparison process in financial reports between companies and financial markets around the world and thus return benefits to both investors and insurance companies. (Mahmoud \& Al-Shammari, 2020).

- IFRS 4 did not define any specific conditions for the initial measurement process for insurance contracts, which was negatively reflected in the different policies followed and their inconsistency between the subsidiaries and the parent company from the policy of using the historical value and the fair value (Lucas, 2020).

The Financial Reporting Standard (Insurance Contracts) (17) came to address this imbalance as it required for initial recognition to group contracts according to groups within a portfolio, then groups of contracts are recognized on the earlier date for the following dates:

- The start date of the coverage period.

- The date on which the first payment from the policyholder becomes due (or received if there is no due date in the contract);

- When a group of contracts becomes onerous, the contract is considered onerous when the total of (realized cash flows in addition to any cash flows previously recognized in addition to any cash flows resulting from the contract at that date) represent a net outflow. (IFRS 17, IFRS Foundation 2020).

All companies that issue insurance contracts are required to account for all insurance contracts in a manner that provides the following: (IFRS 17, The IFRS Foundation 2017)

A greater view of the sources of profit within the business such as underwriting activities, expenses management, investment activities and others.

- Estimating the present value of the obligations that arise from the insurance contracts at the date of each report.

- Determine the extent, nature, timing, and risks associated with the cash flows of insurance contracts.

- Use one of the following three basic approaches to accounting for insurance contracts as follows:

1-General form; As it is applied to all insurance contracts issued with the exception of contracts that apply to the two approaches mentioned below.

2-Variable fee approach; It is applied to insurance contracts that contain the benefits of direct profit sharing, where the policyholder is entitled to obtain a substantial share of the profits from a group of specific investment assets, and therefore the commitment is measured based on the obligation to pay the policyholder and the commitment is equal to the value of the investment after deducting the investment management fees that it charges Insurance company.

3- Premium allocation approach; It is a simplified model from the general model, and it covers short-term insurance contracts that are for one year or less, as well as insurance contracts in which the application of the premium allocation approach in measuring the remaining coverage obligations does not lead to a result that is fundamentally different from that which would result from the application of the general model.

It is expected that applying of the new standard will result in increasing transparency about current and future profitability, which provides comparability through creating a unified framework for all insurance contracts, which in turn reflects updated information on cash flows arising from insurance contracts. (Swiss, Re., 2018).

\subsection{Previous Studies and Development of Hypotheses}

A number of studies have dealt with issues related to the expected impact of applying IFRS 17 on several variables, and many studies have dealt with the quality of financial reports as a dependent variable for the application of financial reporting standards in general, but there is a scarcity of studies - according to the researchers' knowledge - that have linked the expected impact to apply the standard to the quality of financial reporting. The study of Clark et al. (2020) examined the expected impact of applying IFRS 17 on the expected profits to be distributed by insurance companies in a number of European countries. It is unlikely that the requirements will change due to the application of Financial Reporting Standard 17 regarding the flow of distributable profits for new businesses with low profitability and / or high capital requirements. However, the standard may constitute a constraint on the timing of dividend distribution in the case of products that have high profitability and / Or low capital requirements. While the study of Al-Mashhadani and Al-Zubaidi (2020) dealt with the challenges of applying the standard in the Iraqi environment, where the study that used the questionnaire as a measuring tool found that there are fundamental differences between the accounting requirements for insurance contracts according to the unified accounting system used in banks and insurance companies and the requirements of IFRS 17, and that the most prominent challenges facing Iraqi insurance companies are summarized in choosing the method used for initial and subsequent measurement of insurance contracts, estimating future cash flows of contracts and choosing appropriate discount rates, in addition to determining the margin of contractual service for insurance contracts. As for the study of Longonia (2019), that linked the application of IFRS 17 to the value of the company, where the researcher conducted a survey of the impact of 50 potential events that could result from applying the standard on investors, and then the researcher analyzed the adjusted market returns for the most 16 events affected of standard application. In general, the study found that the application of the standard leads to reducing the value of the company, and that the negative impact on the value of the company was greater for large insurance companies with low growth opportunities. The Sotona (2018) focused on assessing risks, especially 
mortality risks, in relation to IFRS (17), and concluded that the assessment of risks in general and mortality risks in particular will be more transparent within the disclosures in the financial statements according to Standard (17), but this requires doing a change in accounting and actuarial policies with respect to risk, and a modification of the existing actuarial models for pricing, development, control and accounting for risks. While the Yanik and Bas (2017) provided a general evaluation of IFRS 17 and concluded by following a set of methods, including case studies and interviews with investors and employees of insurance companies that the standard will be beneficial to investors and insurance companies alike, by providing disclosure requirements. With the aim of increasing the transparency of all insurance contracts prepared by the companies that issue them in accordance with International Financial Reporting Standards, especially since insurance liabilities will be recognized using fair values instead of the historical cost, thus providing users of financial statements with more effective and accurate information. In the study of Suwaidan et al. (2018), it was found that through the distribution of questionnaires and interviews with auditors about the suitability of financial reporting standards for small and medium-sized enterprises, the auditors 'support for the existence of international standards for establishments, and that these standards contribute to meeting the needs of users of the financial statements of these establishments. It also increases the efficiency of the prepared financial statements and their ability to reflect the financial position of the enterprise. The study also found that the weak and sometimes absent of internal control systems in small and medium-sized enterprises in Jordan, are among the most obstacles to implementing the new standards in these enterprises.

Many international organizations, especially those related to auditing, have presented studies on IFRS17, where Aon Plc (2020) studied the effect of applying the standard on performance indicators through the use of experts, it is concluded that the application will increase transparency and understanding of the financial statements. It also concluded that credit rating agencies do not expect that moving to implement IFRS 17 will have a direct impact on the rating of insurance companies, also the study indicated that it is important at the beginning of the application to pay attention to the disclosures related to the regulatory capital and the adjusted return on equity at a discount rate, furthermore, the financial leverage will be affected as a result of the application, so analysts must rely on other indicators. It was also pointed out the importance of including disclosures in tables that include how to generate operating profits from ongoing, new, and discontinued businesses. In the study of Price water house Coopers-PWC (2019), which dealt with the impact of applying IFRS (17) on the performance of European insurance companies by analyzing the expected performance indicators of the 20 largest European insurance companies, it was found that the transition to IFRS 17 will work on abolishing the profit in the beginning by reducing the initial returns for some types of new insurance, and the recognition of profits will be postponed for some insurance products other than life insurance, which in turn will lead to early recognition of losses. As for Swiss Re (2018), in cooperation with Deloite, KPMG and IFB, it indicated that the application of IFRS (17) will bring benefits related to providing detailed information about the performance of the investment and underwriting, in addition to that the revenues and expenses of the underwriting are recognized over time in a way that allows comparison. With other non-insurance activities, it provides important updated information to the market related to liabilities, including the value of options and guarantees, and the standard reflects the time value of money, in addition to the assumptions for evaluating contract obligations reflect the characteristics of the contract rather than the risks related to the investment activity.

As for the studies that dealt with the impact of adopting financial reporting standards in general on the quality of financial reports, they are many, despite the scarcity of linking them with the application of IFRS (17). In Salah \& Salam (2018) study, it aimed to find out if the adoption of international financial reporting standards would be of greater quality compared with the application of local accounting standards in Taiwan, where the quality of financial reports was determined through three characteristics: profit management, recognition of losses in the correct time, and appropriateness of value, the study found that the application of financial reporting standards reduced the earnings management. Musa (2019) is similar to its predecessor by adopting the same standards to measure the quality of financial reports, and concluded that adopting international financial reporting standards increases the quality of financial reports, by reducing earnings management. The study of Peña \& Franco (2016) added that the size of the company played a positive role in the relationship between the adoption of compulsory financial reporting standards and the quality of financial reports in Britain, but in France there was no effect between the adoption of financial reporting standards and the quality of financial reports, as the study followed the quantitative approach to arrive at Results by identifying the discriminatory risks of share returns and using profit management models to measure the quality of financial reports. The studies by Osasere and Ilaboya (2018) and Yurisandi and Puspitasari (2015) are concerned with the change that occurs in the quality of financial reports after the adoption of international financial reporting standards, the fundamental and enhanced qualitative characteristics included in the conceptual framework of accounting have been adopted to define the quality, where it found statistically significant differences for the period after applying international financial reporting standards compared to the period before implementation, by increasing the quality of financial reports after applying the international financial standards measured by qualitative qualities. Depending on literature review and previous studies, researchers formulated the main hypotheses of the study, which is this:

H01: There is no expected statistically significant impact at the level of ( $\alpha \geq 05.0)$ for applying IFRS (17) on the quality of the financial reports of Jordanian insurance companies.

It is divided into the sub-hypotheses: 
H01-1: There is no expected statistically significant impact at the level of $(\alpha \geq 05.0)$ for applying IFRS (17) on the relevance of financial reports of Jordanian insurance companies.

H01-2: There is no expected statistically significant impact at the level of $(\alpha \geq 05.0)$ for applying IFRS (17) on the faithful representation of the financial reports of Jordanian insurance companies.

H01-3: There is no expected statistically significant impact at the level of $(\alpha \geq 05.0)$ for applying IFRS (17) on the comparability of the financial reports of Jordanian insurance companies.

H01-4: There is no expected statistically significant impact at the level of $(\alpha \geq 05.0)$ for applying IFRS (17) on the understandability of the financial reports of Jordanian insurance companies.

H01-5: There is no expected statistically significant impact at the level of $(\alpha \geq 05.0)$ for applying IFRS (17) on the verifiability of the financial reports of Jordanian insurance companies.

H01-6: There is no expected statistically significant impact at the level of ( $\alpha \geq 05.0)$ for applying IFRS (17) on the timeliness of the financial reports of Jordanian insurance companies.

\section{Research Method}

The study relied as a first step on the exploratory approach, and this approach is useful in case of planning to explain the nature of the problem or phenomenon and helps in how to deal with it, especially in case of uncertainty (an expected effect of a standard that has not yet been applied). The second step was to rely on the inferential descriptive (analytical) approach to explain the researched phenomenon, relying on all facts and data, classifying them, and then processing the data and analyzing it to extract its significance and arrive at conclusions or generalizations about the phenomenon or problem (Sekaran \& Bougie, 2016: 103).

\subsection{Sample and Data Collection}

The study population represents all the (24) insurance companies, where (120) questionnaires were distributed to the employees of the financial department using the random sample method, with (5) questionnaires on each company, and (97) questionnaires were retrieved at (80.8\%). From the distributed questionnaires, and processing the questionnaires, it became clear that (3) questionnaires were not fully filled out, so they were excluded, so the number of questionnaires valid for statistical analysis is (94) questionnaires with a percentage of (78.3\%) of the distributed questionnaires.

\subsection{Data Validity and Reliability}

The questionnaire was presented, in its initial form, to a group of academics specialized in Jordanian universities, to ensure the validity and appropriateness of the content of the questionnaire's paragraphs. Cronbach's Alpha was relied on in measuring the stability of the internal consistency of the paragraphs of the study questions, the results of which are shown in Table 1.

\section{Table 1}

Cronbach Alpha

\begin{tabular}{cccc}
\hline Paragraph & Cronbach & Main & Characteristic \\
\hline 6 & 0.835 & First & Relevance \\
6 & 0.751 & Second & Faithful Representation \\
5 & 0.884 & Third & Comparability \\
5 & 0.856 & Fourth & Understandability \\
5 & 0.761 & Fifth & Verifiability \\
5 & 0.896 & Sixth & Timeliness \\
\hline 32 & general & & 0.932 \\
\hline
\end{tabular}

Source: researchers depend on SPSS results
Table 2

Normal Distribution test (K-S)

\begin{tabular}{llcc}
\hline Main Question & Characteristic & Sig & K-S \\
\hline First & Relevance & 0.245 & 1.024 \\
Second & Faithful Representation & 0.380 & 0.909 \\
Third & Comparability & 0.075 & 1.282 \\
Fourth & Understandability & 0.109 & 1.207 \\
Fifth & Verifiability & 0.060 & 1.324 \\
Sixth & Timeliness & 0.097 & 1.231 \\
\hline
\end{tabular}

Source: researchers depend on SPSS results

All internal consistency parameters mentioned in Table 1 are a good indication of the reliability of the study tool and its reliability in statistical analysis. internal consistency constant of a coefficient (0.70) (Sekaran \& Bougie, 2016: 325).

\subsection{Normal Distribution}

The Kolmogorov-Smirnov Test, which is used to identify a normal (moderate) distribution of data if the (Sig) value is greater than (0.05) was performed (Field, 2013: 246).

Based on the test data shown in Table 2, it is clear that the data distribution was normal, and through the value of (Sig) for all questions, which have values greater than (0.05).

\subsection{Descriptive Analysis}

The mean, standard deviations, rank, relative weight and relative importance were calculated in order to find out the direction of the opinions of the study, where the study tool was divided to find out the relative importance of each of its paragraphs according 
to the five-year Likert scale where a gradual scale was developed to judge the results of the study (Subedi, 2016), the tables in appendix (3-8) clarify the descriptive results for each dimension (main question). Table 3 shows the data for the paragraphs related to the expected impact of applying IFRS 17 on relevance, where it was found that the mean ranged between (3.88-4.21), which led to a high relative importance for all paragraphs. Paragraph (1) which states: "The use of IFRS (17) for fair value in measuring insurance contracts will assist the user in the positive decision-making process "on the first rank, while paragraph (6) which states: "The accounting information that will be provided by the application of IFRS (17) will necessarily require an influence on the decision-making process", achieved the last rank. Table 4 shows the data for the paragraphs related to the expected impact of applying IFRS 17 on faithful representation, it was found that the mean ranged between (3.94-4.22), which are high averages that led to a high relative importance for all paragraphs. Paragraph (12) which states: "Adoption of the standard will require that in the estimation of future cash flows, all accounting information about the amounts, timing and uncertainty be reflected", in the first, while paragraph (8) The last rank, which states "The use of new standard in estimating cash flows will be based mainly on objective assumptions relied on the company's management decisions". While the expected impact of IFRS 17 on the comparability was explained in Table 5, Where it was found that the mean ranged between (4.13-4.33), which are high averages that led to a high relative importance for all paragraphs, as Paragraph (14), which states "The application of the new standard for unifying the assessment of unearned income at the beginning of insurance contracts will provide the possibility of comparison between the different insurance companies "has achieved the first, while paragraph (13) has achieved the last rank, which states:" IFRS (17), upon application, allows retrospective amendment will facilitate comparison with pre-application insurance contracts". Table 6 explains the expected impact on comparability, where it was found that the mean ranged between (3.82-3.94), which are high averages that led to a high relative importance for all paragraphs. Paragraph (19) which states: "The disclosures imposed through the application of the new standard will enable the concerned parties to understand the valuation methods used for insurance contracts", ranked first, while paragraph (22) achieved the last rank, which states:" The method of presenting the income statement as a result of applying the financial reporting standard (insurance contracts) (17) will enable the concerned parties to understand the results of insurance services from insurance revenues and expenses resulting from the change in the time value and assumptions related to financial risks". As for the impact on verifiability, Table 7 indicates that the mean ranged between (4.01-4.14), which are high averages that led to a high relative importance for all paragraphs, as paragraph (27) achieved the first rank, it stated: "The application of IFRS (17) will enable tracking of insurance revenues and expenses and verify their accuracy, while paragraph (24) has achieved The last rank, which states "The requirements for applying the new standard will allow access to the same results when choosing a discount rate for estimating cash flows using the same assumptions and for different individuals". Table (8) shows the data for the paragraphs related to the timeliness, as it was found that the mean ranged between (3.90-3.99), which are high averages that led to a high relative importance for all paragraphs, as paragraph (31) which states: "The requirements of applying IFRS 17 will provide accounting information to assess the impact of contracts on financial performance in a timely manner", Has achieve the first rank, while paragraph (29) achieved the last rank, which states: "The requirements of applying the new standard will enable the presentation of accounting disclosures related to changes in accounting policies, if they occur and in a timely manner". The following table, summarizes the descriptive analysis results for the expected impact of IFRS 17 implementation on quality of financial reports measured by qualitative characteristics.

Table 9

Summary of descriptive analysis results for all study axes

\begin{tabular}{|c|c|c|c|c|c|}
\hline No. of axis & Characteristic & Relative important & Rank & Standard Deviation & Mean \\
\hline First & Relevance & High & 3 & 0.581 & 4.09 \\
\hline Second & Faithful Representation & High & 2 & 0.492 & 4.14 \\
\hline Third & Comparability & High & 1 & 0.495 & 4.24 \\
\hline Fourth & Understandability & High & 6 & 0.730 & 3.87 \\
\hline Fifth & Verifiability & High & 4 & 0.510 & 4.07 \\
\hline \multirow[t]{2}{*}{ Sixth } & Timeliness & High & 5 & 0.690 & 3.95 \\
\hline & 1 indicator & High & & 0.435 & 4.06 \\
\hline
\end{tabular}

Source: researchers depend on SPSS results

\subsection{Results of hypothesis testing}

The One Sample T-Test was used to test the study hypotheses, where it was examined whether the mean of a sample differs significantly from the population mean, and to find the difference between the mean of the sample and the value of the parameter in the scale which is number (3) (Al-Najjar, Al-Najjar and Al-Zaabi, 2020: 211) and this test is used if the normal distribution is achieved (Al-Zoubi \& Al-Talafha, 2012: 195). If the value of the effect size is less than (0.20), the size of the effect is considered small, and if the value of the effect size ranges between $(0.20$ - less than 0.80$)$ then the size of the effect is considered medium, and if the effect size exceeds (0.80), the size of the effect is considered large (Leech, Barrett \& George, 2015: 556). The following results were reached: 
Table 10

Hypothesis testing

\begin{tabular}{|c|c|c|c|c|c|c|c|}
\hline No. of hypotheses & T Calculated & T"Table" & $\mathrm{N}$ & Result HO & T Sig & DF & The expected impact \\
\hline Sub (1) & 18.157 & 1.9855 & 94 & Refused & 0.00 & 1 & Large \\
\hline Sub (2) & 22.481 & 1.9855 & 94 & Refused & 0.00 & 1 & Large \\
\hline Sub (3) & 24.207 & 1.9855 & 94 & Refused & 0.00 & 1 & Large \\
\hline Sub (4) & 11.610 & 1.9855 & 94 & Refused & 0.00 & 1 & Large \\
\hline Sub (5) & 20.403 & 1.9855 & 94 & Refused & 0.00 & 1 & Large \\
\hline Sub (6) & 13.361 & 1.9855 & 94 & Refused & 0.00 & 1 & Large \\
\hline Main & 23.698 & 1.9855 & 94 & Refused & 0.00 & 1 & Large \\
\hline
\end{tabular}

Source: researchers depend on SPSS results

It was found that there was a statistically significant effect $(\alpha \leq 0.05)$ for all the hypotheses of the study in terms of the value of (Sig), which is less than (0.05) and also in terms of the calculated value, which was greater than the tabular value (1.9855), at one degree of freedom (DF), and accordingly It can be said that there is a significant impact of applying IFRS(17) on the quality of the financial reports of Jordanian insurance companies, and it can be inferred that the application of the international reporting standard had its effect on (comparability, faithful representation, relevance, verifiability, and timeliness and understandability) respectively.

\section{Conclusions and recommendations}

It was found that the expected impact of applying the International Financial Reporting Standard "17" of insurance contracts on the quality of financial reports is significant and positive, especially on the comparability of financial reports, faithful representation and relevance.

It was found also by reviewing the answers of the study sample that received the highest averages, that the application of IFRS 17 by unifying the assessment of unearned income at the beginning of the insurance contracts will provide the possibility of comparison between the different insurance companies, and the recognition of insurance revenues and expenses will provide the possibility of comparison between insurance and non-insurance activities.

Researchers recommend working on creating appropriate conditions for the implementation of the standard, by training and qualifying workers, in addition to preparing the systems and software necessary to implement the standard, and they suggest that insurance companies conduct a simulation related to the application of the standard, by classifying existing insurance contracts according to the classifications of the new standard and studying the impact of the application Presumed on accounts, and by various entries, and the need to follow objective assumptions from the company's management for the estimation of cash flows when applying the standard.

\section{References}

Al-Mashhadani, B. N. A. (2020). Challenges of applying IFRS 17 "Insurance Contracts" In the Iraqi environment. Tikrit Journal of Administration and Economics Sciences, $16(49$ part 1), 77-96.

Al-Najjar, F.J., Al - Najjar, N.J., and Al - Zuobi, M.R., (2020), Scientific Research Methods: Applied Perspective, (5th) Edition, Amman, Dar Al-Hamed for Publishing \& Distribution.

Al zobi, M.B., \& Talafha, A. (2012). Statistical System SPSS understanding and analysis the statistical data, (3rd) Edition, Amman, Dar Wael for Publishing.

AON Plc, (2020), The Impact of IFRS 17 on Key Performance Indicators, available at: http://houghtleadership.aonbenfield.com/Documents/20200218_ifrs_17_kpis.pdf, access date: 22/5/2020.

Clark, D., Kent, J., \& Morgan, Ed. (2020). Impact of IFRS 17 on Insurance Product Pricing and Design, Milliman Report, Milliman Inc., available at: https:/us.milliman.com/en/insight/impact-of-ifrs-17-on-insurance-product-pricing-and-design.

Dufrasne, L. " IFRS 17: a comparison with IFRS 4 and an analysis of the impact of its application.

Field, A. (2017). Discovering statistics using IBM SPSS statistics: North American edition. sage.

IFRS Foundation, IFRS 17, Available at: https://www.ifrs.org/issued-standards/list-of-standards/ifrs-17-insurance-contracts/ access date: $3 / 4 / 2020$.

Leech, N. L., Barrett, K. C., \& Morgan, G. A. (2014). IBM SPSS for intermediate statistics: Use and interpretation. Routledge.

Longoni, P. (2019). IFRS 17 Insurance Contracts and Firm Value. Available at SSRN 3589560.

Mahmoud, B. I., \& Al Shammari, S. K. (2020). Requirements for the Application of IFRS 17 in the Iraqi Environment. journal of Economics And Administrative Sciences, 26(119).

Mignolet, F. (2017). A study on the expected impact of IFRS 17 on the transparency of financial statements of insurance companies, thesis for school of management of the ULg.

Musa, A. (2019). the role of IFRS on financial reporting quality and global convergence: a conceptual review.”, International Business and Accounting Research Journal, 3(1), 67-76. 
Osasere, A. O., \& Ilaboya, O. J. (2018). IFRS adoption and financial reporting quality: LASB qualitative characteristics approach. Accounting and Taxation Review, 2(3), 30-47.

Peña, H. F. P., \& Franco, J. B. (2017), Impact of IFRS on the quality of financial information in the United Kingdom and France: Evidence from a new perspective. Intangible Capital, 13(4), 850-878.

Price Water House Coopers-PWC, (2019). New Measures, New Perspective, The Impact of IFRS 17 on Insurance Performance and Reporting", available at: https://www.pwc.co.uk/audit-assurance/assets/pdf/impact-of-ifrs-17-on-insurance-performancereporting.pdf, access date 22/5/2020.

Salah, W., \& Abdel-Salam, A. (2019). The effects of international financial reporting standards on financial reporting quality. Athens Journal of Business \& Economics, 5(3), 221-242.

Sekaran, U., \& Bougie, R. (2012). Research Methods for Business: A Skill Building Approach. $7^{\text {th }}$ ed., NY: John Wiley \& Sons Inc, New York.

Sotona, P. (2018). MORTALITY RISK ASSESSMENT UNDER IFRS 17. 21th International Scientific Conference AMSE: Applications of Mathematics and Statistics in Economics, Czech Republic, Available at: http://www.amseconference.eu/old/2018/wp-content/uploads/2018/10/Sotona.pdf, access date: 12/6/2020

Subedi, P. B. (2016). Using likert type data in social science research: Confusion, issues and challenges. International Journal of Contemporary Applied Sciences, 3(2), 36-49.

Swiss Re (2018). The Impact of IFRS 17 An Outside View, available at: https://www.swissre.com/dam/jcr:7ba0ed33-95d4-436e9872-32d10bd5a888/Asia+CFO+Leadership+Forum+-+IFRS+17+-+Impact+of+IFRS+17.pdf, access date 1/5/2020.

Yanik, S., \& Ece, B. A. S. (2017). Evaluation of IFRS 17 insurance contracts standards for insurance companies. Press Academia Procedia, 6(1), 48-50.

Yurisandi, T., \& Puspitasari, E., (2015), Financial Reporting Quality-Before and After IFRS Adoption Using NiCE Qualitative Characteristics Measurement. Procedia-Social and Behavioral Sciences, 211, 644-652.

Suwaidan, M. S., Qaqish, M. H., Bataineh, H. T., \& Hammad, L. J., (2018). The relevance of applying IFRS for SMEs in Jordan: An explanatory study from the Jordanian auditors' viewpoint, Jordan. Journal of Business Administration, Jordan University, 14(2), 239-260.

\section{Web Sites:}

Amman Stock exchange, www.ase.jo , access date: 20/4/2020, 15/5/2020, 15/7/2020

Jordan Depository center, www.sdc.com.jo , access date: 22/4/2020, 15/5/2020, 15/7/2020

Jordan insurance federation, http://www.joif.org, , access date: 2/4/2020, 15/7/2020.

\section{Appendix}

Table 3

Relevance

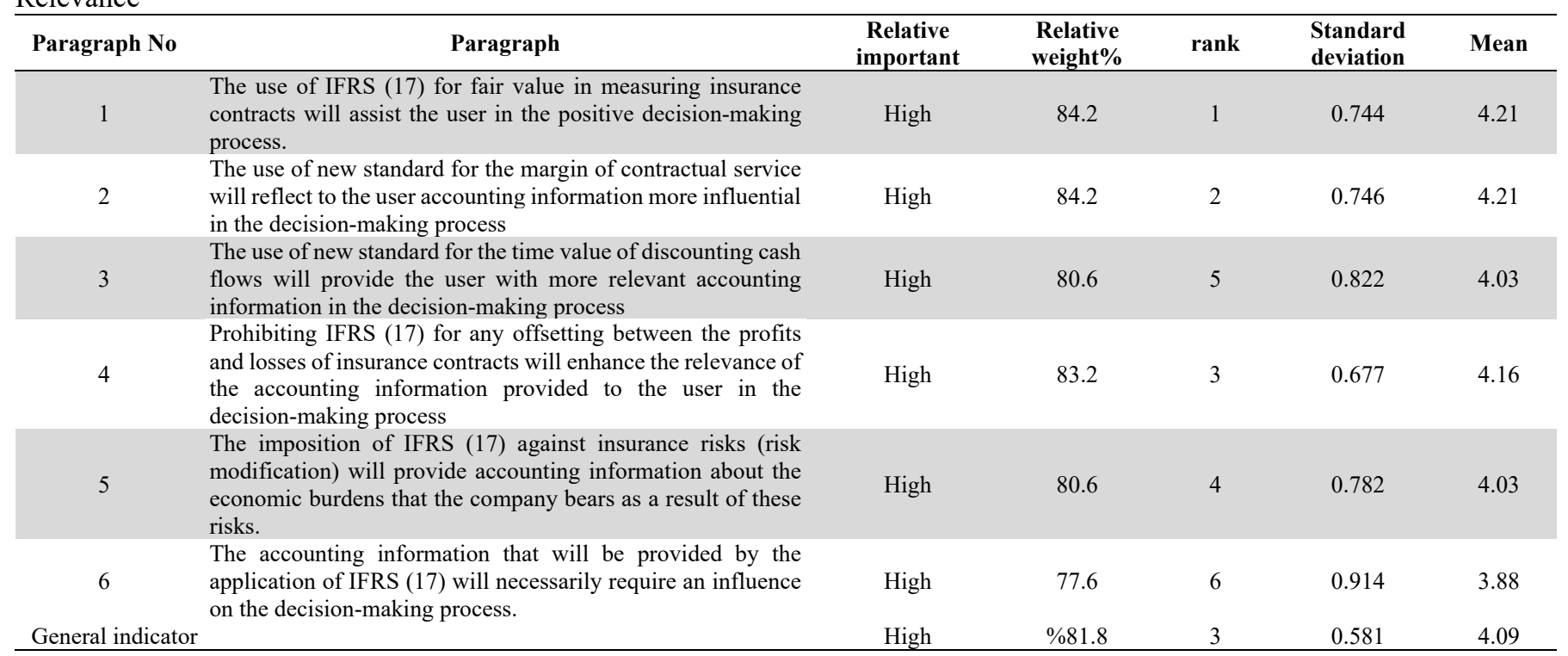

Source: researchers depend on SPSS results 
Table 4

Faithful representation

\begin{tabular}{|c|c|c|c|c|c|c|}
\hline $\begin{array}{l}\text { Paragraph } \\
\text { No. }\end{array}$ & Paragraph & $\begin{array}{l}\text { Relative } \\
\text { Important }\end{array}$ & $\begin{array}{l}\text { Relative } \\
\text { weight } \%\end{array}$ & Rank & $\begin{array}{l}\text { Standard } \\
\text { Deviation }\end{array}$ & Mean \\
\hline 7 & $\begin{array}{l}\text { The application of IFRS (17) will provide the decision maker with accurate } \\
\text { accounting information on the assets and liabilities resulting from the } \\
\text { insurance contract. }\end{array}$ & High & 83.2 & 4 & 0.627 & 4.16 \\
\hline 8 & $\begin{array}{l}\text { The use of new standard in estimating cash flows will be based mainly on } \\
\text { objective assumptions relied on the company's management decisions. }\end{array}$ & High & 78.8 & 6 & 0.948 & 3.94 \\
\hline 9 & $\begin{array}{l}\text { The application of IFRS (17) will provide the decision maker with } \\
\text { complete accounting information on insurance contracts. }\end{array}$ & high & 84.2 & 2 & 0.602 & 4.21 \\
\hline 10 & $\begin{array}{l}\text { The application of IFRS (17) through the use of the general entrance } \\
\text { approach will be reflected in the estimation of future cash flows more } \\
\text { accurately. }\end{array}$ & high & 83 & 5 & 0.842 & 4.15 \\
\hline 11 & $\begin{array}{l}\text { The application of the new standard through the use of the premium } \\
\text { allocation approach will be reflected in the estimation of the residual value } \\
\text { to cover the group of insurance contracts more accurately. }\end{array}$ & high & 83.4 & 3 & 0.771 & 4.17 \\
\hline 12 & $\begin{array}{l}\text { Adoption of the standard will require that in the estimation of future cash } \\
\text { flows, all accounting information about the amounts, timing and } \\
\text { uncertainty be reflected. }\end{array}$ & High & 84.4 & 1 & 0.552 & 4.22 \\
\hline \multicolumn{2}{|c|}{ General indicator } & High & 82.8 & 2 & 0.492 & 4.14 \\
\hline
\end{tabular}

Source: researchers depend on SPSS results

Table 5

Comparability

\begin{tabular}{|c|c|c|c|c|c|c|}
\hline $\begin{array}{l}\text { Paragraph } \\
\text { No. }\end{array}$ & Paragraph & $\begin{array}{l}\text { Relative } \\
\text { important }\end{array}$ & $\begin{array}{l}\text { Relative } \\
\text { weight } \%\end{array}$ & Rank & $\begin{array}{l}\text { Standard } \\
\text { Deviation }\end{array}$ & Mean \\
\hline 14 & $\begin{array}{l}\text { The application of the new standard for unifying the assessment of } \\
\text { unearned income at the beginning of insurance contracts will } \\
\text { provide the possibility of comparison between the different } \\
\text { insurance companies. }\end{array}$ & High & 86.6 & 1 & 0.556 & 4.33 \\
\hline 15 & $\begin{array}{l}\text { The application of the new standard by standardizing disclosure } \\
\text { information to insurance companies about the evaluation methods } \\
\text { used for insurance contracts will provide the possibility of } \\
\text { comparison between similar insurance contracts. }\end{array}$ & High & 84.2 & 4 & 0.526 & 4.21 \\
\hline 16 & $\begin{array}{l}\text { The application of the new standard by recognizing insurance } \\
\text { revenues and expenses will provide comparability between } \\
\text { insurance and non-insurance activities. }\end{array}$ & High & 85.6 & 2 & 0.629 & 4.28 \\
\hline 17 & $\begin{array}{l}\text { The implementation of the new standard by grouping and } \\
\text { managing insurance contracts of similar risks together into one } \\
\text { portfolio will facilitate the comparison process between groups of } \\
\text { similar portfolios. }\end{array}$ & High & 84.6 & 3 & 0.663 & 4.23 \\
\hline
\end{tabular}

Source: researchers depend on SPSS results

\section{Table 6}

Understandability

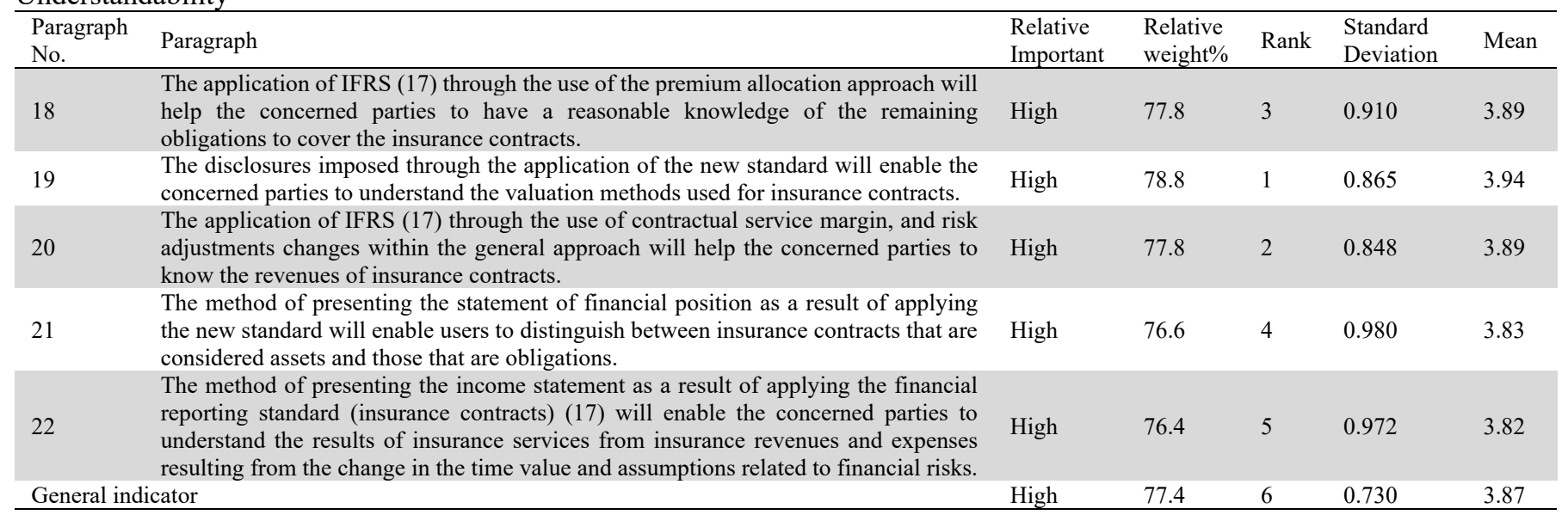


Table 7

Verifiability

\begin{tabular}{|c|c|c|c|c|c|c|}
\hline Paragraph No. & Paragraph & $\begin{array}{l}\text { Relative } \\
\text { Important }\end{array}$ & $\begin{array}{l}\text { Relative } \\
\text { weight } \%\end{array}$ & Rank & $\begin{array}{l}\text { Standard } \\
\text { Deviation }\end{array}$ & Mean \\
\hline 23 & $\begin{array}{l}\text { The requirements of applying IFRS (17) will allow } \\
\text { reach to the same results for the values of the } \\
\text { remaining obligations in the event of measurement } \\
\text { and for different individuals. }\end{array}$ & High & 82.8 & 2 & 0.727 & 4.14 \\
\hline 24 & $\begin{array}{l}\text { The requirements for applying the new standard will } \\
\text { allow access to the same results when choosing a } \\
\text { discount rate for estimating cash flows using the same } \\
\text { assumptions and for different individuals. }\end{array}$ & High & 80.2 & 5 & 0.680 & 4.01 \\
\hline 25 & $\begin{array}{l}\text { The application of the new standard will enable } \\
\text { tracking of non-insurance components in insurance } \\
\text { contracts that fall within the scope of another } \\
\text { standard. }\end{array}$ & High & 81 & 3 & 0.821 & 4.05 \\
\hline 26 & $\begin{array}{l}\text { The application of the new standard will enable the } \\
\text { tracking of assets and liabilities resulting from } \\
\text { insurance contracts and verification of their accuracy. }\end{array}$ & High & 80.4 & 4 & 0.718 & 4.02 \\
\hline 27 & $\begin{array}{l}\text { The application of IFRS (17) will enable tracking of } \\
\text { insurance revenues and expenses and verify their } \\
\text { accuracy. }\end{array}$ & High & 82.8 & 1 & 0.598 & 4.14 \\
\hline General indicator & & High & 81.4 & 4 & 0.510 & 4.07 \\
\hline
\end{tabular}

Source: researchers depend on SPSS results

\section{Table 8}

Timeliness

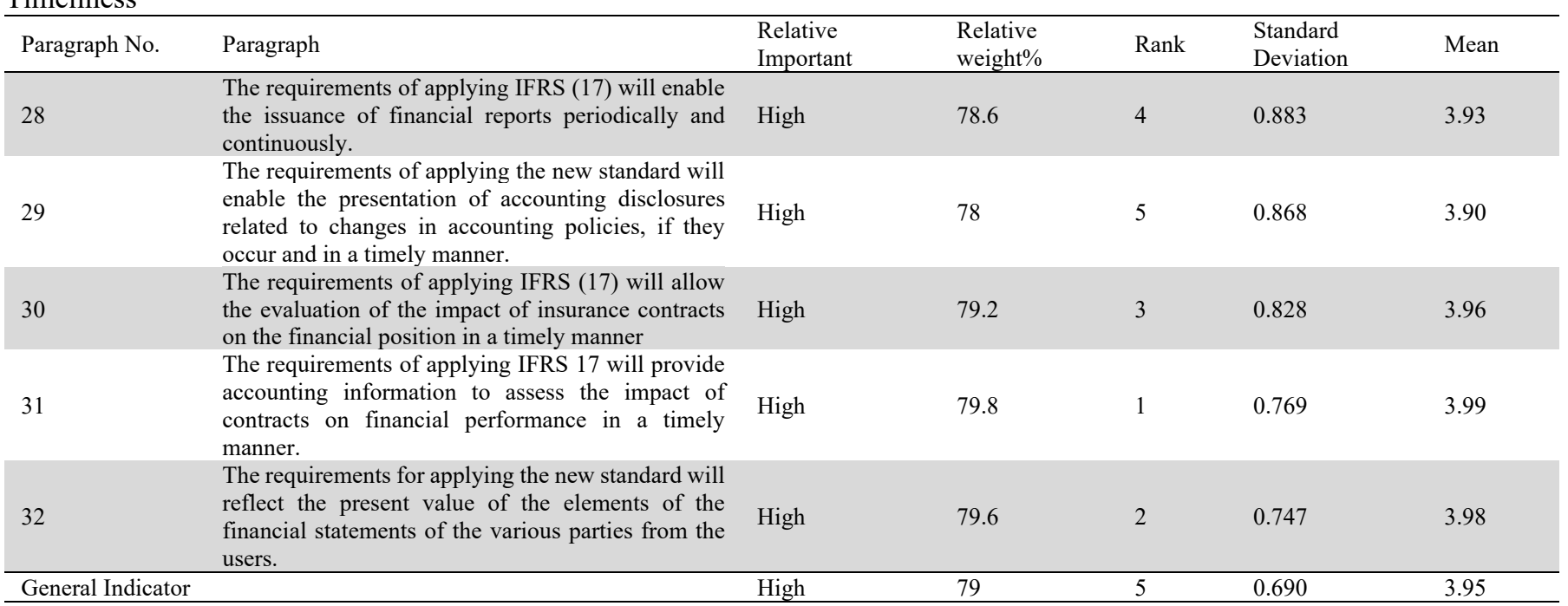

